\title{
PELANGGARAN PRINSIP KERJA SAMA DALAM PEMBELAJARAN BAHASA INDONESIA DI SMK BATIK 1 SURAKARTA
}

\author{
Fasha Nabilah Aprilliani, Muhammad Rohmadi, Atikah Anindyarini \\ Universitas Sebelas Maret \\ Surel: fashanabilahaprilliani@student.uns.ac.id
}

\begin{abstract}
Abstrak: Tujuan penelitian ini adalah untuk menjelaskan dan mendeskripsikan (1) wujud pelanggaran prinsip kerja sama dalam interaksi pembelajaran bahasa Indonesia di SMK Batik 1 Surakarta; (2) tujuan pelanggaran prinsip kerja sama dalam pembelajaran bahasa Indonesia di SMK Batik 1 Surakarta; (3) fungsi pelanggaran prinsip kerja sama dalam interaksi pembelajaran bahasa Indonesia di SMK Batik 1 Surakarta. Penelitian ini merupakan penelitian kualitatif deskriptif dengan sumber data utama yaitu rekaman kegiatan pembelajaran bahasa Indonesia di kelas X Desain Komunikasi Visual dan XI Pemasaran. Teknik pengambilan data dalam penelitian ini menggunakan teknik observasi dan teknik wawancara mendalam. Teknik pengambilan subjek penelitian menggunakan teknik purposive sampling. Uji validitas data yang digunakan ialah triangulasi teknik dan triangulasi teori. Teknik analisis datanya menggunakan teknik analisis interaktif. Berdasarkan hasil penelitian, ditemukan tuturan yang melanggar satu maksim prinsip kerja sama dan tuturan yang melanggar dua maksim prinsip kerja sama, disebut dengan pelanggaran maksim tunggal dan pelanggaran maksim ganda. Pelanggaran maksim yang terjadi tersebut tidak hanya dilakukan oleh guru saja melainkan dilakukan juga oleh siswa. Pelanggaran maksim memiliki sebelas tujuan. Pelanggaran maksim prinsip kerja sama yang dilakukan baik oleh siswa maupun guru memiliki fungsi masing-masing. Fungsi bahasa terkait pelanggaran maksim terdapat 7 fungsi.
\end{abstract}

Kata kunci: prinsip kerja sama, maksim, tujuan pelanggaran, fungsi pelanggaran.

\section{COLLABORATION OF COOPERATION PRINCIPLES IN INDONESIAN LANGUAGE LEARNING IN BATIK 1 VOCATIONAL SCHOOL, SURAKARTA}

\begin{abstract}
The purpose of this research is to explain and describe (1) a form of violation of the principle of cooperation in the interaction of learning Indonesian in SMK Batik 1 Surakarta; (2) the purpose of violating the principle of cooperation in learning Indonesian in SMK Batik 1 Surakarta; (3) the function of violating the principle of cooperation in the interaction of learning Indonesian in SMK Batik 1 Surakarta. This research is descriptive qualitative research with main data source that is recording of learning activity of Indonesia in class X Visual Communication Design and XI Marketing. Technique of data retrieval in this research use observation technique and deep interview technique. Technique of taking research subject using purposive sampling technique. The data validity test used is triangulation technique and triangulation theory. Data analysis techniques using interactive analysis techniques. Based on the results of the research, found a speech breaking a maximum of cooperation and speech principles that violate two maxims of cooperation principles, called a single maximal offense and a double maximal offense. Violation of maxim that happened not only done by teacher but also done by student. Maximum violations have 11 violation objectives. Maximum violation of the principle of cooperation done by both students and teachers have their respective functions. The function of language related to maximal violation have 7 functions.
\end{abstract}

Keywords: principle of cooperation, maxim, purpose of violation, function of violation.

BASASTRA Jurnal Bahasa, Sastra, dan Pengajarannya

Volume 6 Nomor 2, Oktober 2018, ISSN 2302-6405 


\section{PENDAHULUAN}

Manusia sebagai makhluk sosial menggunakan bahasa sebagai alat untuk saling berkomunikasi, berinteraksi, dan mengekspresikan diri dalam masyarakat. Sebagai alat komunikasi bahasa memiliki tiga unsur, pertama sebagai alat komunikasi untuk menyampaikan pesan yang berkonotasi perasaan (emotif), kedua berkonotasi sikap (afektif), dan ketiga berkonotasi pikiran (penalaran) atau secara rinci fungsi bahasa adalah fungsi emotif, afektif, dan penalaran (Suriasumantri, 1996:301).

Dalam kegiatan berkomunikasi, penutur memiliki tujuan tertentu yang ingin disampaikan kepada mitra tutur. Agar mitra tutur memahami apa yang ingin disampaikan, penutur harus memahami konteks tuturannya. Pesan bahasa yang memberikan makna ujaran dan tuturan yang dikaitkan dengan konteks, yakni kapan, di mana, dan dalam kondisi bagaimana, mengapa tuturan itu disampaikan, dan bagaimana cara mewujudkannya serta kepada siapa tuturan itu diberikan (Sulistyo, 2013: 1). Seringkali terjadi kesalahan interpretasi antara penutur dan mitra tutur. Hal ini karena mitra tutur tidak memahami konteks yang diinginkan oleh penutur sehingga komunikasi sering tidak efektif. Oleh karena itu, dalam berkomunikasi terdapat aturan-aturan agar penutur dan mitra tutur dapat bekerja sama mewujudkan proses komunikasi yang baik dan tujuan komunikasi dapat tercapai.

Komunikasi juga terjadi dalam dunia pendidikan dan pengajaran bahasa. Bahasa memegang peranan penting dalam berbagai bidang. Oleh karena itu, berbahasa secara baik dan benar perlu diajarkan semenjak dini. Pengajaran bahasa perlu diimplikasikan pada pembelajaran di lembaga pendidikan. Sekolah sebagai institusi pendidikan formal, memiliki fungsi dan peran penting dalam melahirkan generasi muda yang terampil berbahasa Indonesia dengan baik dan benar. Pelajaran bahasa Indonesia menjadi ajang untuk membentuk peserta didik yang terampil berbahasa. Pelajaran bahasa Indonesia melatih dan mengajari peserta didik untuk terampil berbahasa melalui keterampilan menyimak, berbicara, membaca, dan menulis. Melalui penguasaan keterampilan berbahasa tersebut, peserta didik diharapkan menjadi generasi yang kreatif, cerdas, berbudaya, dan sopan dalam berkomunikasi. Peserta didik juga nantinya akan mampu berkomunikasi dengan baik secara lisan maupun tulisan dengan semua orang sesuai dengan konteksnya.

Pembelajaran adalah proses interaksi antara peserta didik dengan pendidik dan sumber belajar pada suatu lingkungan belajar (Depdiknas, 2003: 7). Kegiatan belajar mengajar dapat berjalan dengan baik apabila siswa dan guru saling berinteraksi untuk berdiskusi guna mencapai tujuan. Belajar mengajar juga menuntut peserta didik untuk berinteraksi dengan sumber belajar. Interaksi peserta didik dengan guru maupun sumber belajar memerlukan media, metode, strategi, maupun pendekatan pembelajaran yang sesuai dengan kondisi kelas dan karakteristik siswa. Dalam penggunaan media, metode, strategi, maupun pendekatan pembelajaran ini, terjadi berbagai bentuk aplikasi prinsip kerja sama.

Dalam setiap proses pembelajaran, guru memegang peranan yang penting. Sari (2013: 187) mengatakan bahwa pembelajaran sebagai tempat pelaksanaan prinsip kerja sama di kelas, dominan terjadi ketika situasi formal, yaitu saat guru menjelaskan materi pembelajaran. Akan tetapi, pembelajaran menurut kurikulum 2013, menuntut siswa berperan aktif dan guru hanya sebagai fasilitator maupun narasumber. Hal ini menjadikan pelaksaan prinsip kerja sama tidak hanya terjadi dalam situasi formal satu arah (guru menjelaskan saja), tetapi terjadi juga dalam diskusi kelas. Siswa diberikan kebebasaan untuk menyampaikan pendapatnya atau menjelaskan kembali materi menurut sudut 
pandangnya. Selama siswa menyampaikan pendapatnya inilah, prinsip kerja sama cenderung dilanggar.

Peran sebagai fasilitator mengharuskan seorang guru semaksimal mungkin mendesain proses pembelajaran yang membantu peserta didik agar berkembang secara positif. Agar peserta didik mampu berkembang secara positif, penggunaan bahasa seorang guru harus diperhatikan dengan baik. Penggunaan tindak tutur guru selama pembelajaran memiliki peran penting. Hal ini dikarenakan setiap tuturan yang dituturkan oleh guru dalam pembelajaran berisi keseluruhan kegiatan pembelajaran.

Tindak tutur digunakan untuk mengungkapkan maksud komunikatif penutur dalam menghasilkan tuturan kepada mitra tutur (Rafika, 2016: 101). Maksud komunikatif seorang penutur dapat dipahami oleh mitra tutur apabila didukung dengan keadaan lingkungan dan konteks. Berdasarkan jenisnya, tindak tutur menurut Austin dibagi menjadi tiga yaitu, lokusi, ilokusi, dan perlokusi.

Prinsip kerja sama memiliki empat maksim percakapan yaitu, maksim kuantitas, maksim kualitas, maksim relevansi, dan maksim pelaksanaan. Penyimpangan terhadap keempat maksim tersebut sering terjadi dalam pembelajaran bahasa Indonesia. Hal ini menjadikan proses pembelajaran bahasa Indonesia terganggu dan kurang efektif sehingga tujuan pembelajaran sulit untuk tercapai. Adanya penyimpangan prinsip kerja sama ini didorong oleh keadaan tertentu dan juga dengan tujuan tertentu.

Pelanggaran maksim dalam prinsip kerja sama memiliki tujuan. Tujuan pelanggaran tersebut menurut Fajar (2009: 62) adalah sebagai berikut; memberikan informasi, (2) mendidik, (3) menyenangkan/menghibur, dan mengajukan suatu tindakan/persuasi. Berdasarkan tujuan berkomunikasi tersebut, data hasil observasi kemudian dianalisis tujuan pelanggaran maksimnya. Berdasarkan teori-teori tujuan berbahasa, ditemukan 11 kategori tujuan pelanggaran maksim dalam penelitian ini yaitu, memberikan informasi, melucu, menyindir, menggaggu, menghina, memerintah, memarahi, mengalihkan perhatian, mendidik, dan menggoda.

Tidak dapat dipungkiri tuturan yang melanggaran maksim dalam prinsip kerja sama juga memiliki fungsi. Sama halnya dengan komunikasi, pelanggaran yang dilakukan oleh guru maupun siswa pasti memiliki fungsi. Tuturan yang dihasilkan oleh guru dan siswa dalam kelas merupakan sebuah bahasa. Bahasa tuturan tersebut kemudian dianalisis apakah terdapat pelanggaran prinsip kerja sama di dalamnya. Berdasarkan hal tersebut, teori fungsi bahasa milik Halliday (1973: 27) dijadikan sebagai landasan untuk menemukan fungsi pelanggaran prinsip kerja sama. Ketujuh fungsi bahasa tersebut yakni fungsi instrumental, fungsi regulasi, fungsi representatif, fungsi interaksional, fungsi personal, fungsi heuristik, dan terakhir fungsi imajinatif. Secara singkat, tuturan yang melanggar prinsip kerja sama kemudian dianalisis kembali menggunakan teori fungsi bahasa untuk menemukan fungsi pelanggaran prinsip kerja sama.

Objek kajian dalam penelitian ini adalah interaksi guru dan siswa kelas $\mathrm{X}$ dan XI pada mata pelajaran bahasa Indonesia di SMK. Penting bagi siswa maupun guru untuk mengetahui kapan harus menaati prinsip kerja sama dan kapan harus melanggar prinsip kerja sama. Keadaan yang terjadi di lapangan, masih banyak yang tidak memahami konteks pelanggaran maksim kerja sama. Guru maupun siswa banyak yang salah mengaplikasikan prinsip kerja sama ini dalam pembelajaran bahasa Indonesia di kelas.

Penelitian yang dilakukan di SMK Batik 1 Surakarta, menghasilkan banyak temuan penyimpangan prinsip kerja sama baik secara sengaja maupun tidak disengaja. Penyimpangan yang dilakukan tersebut terbagi menjadi penyimpangan tunggal, satu maksim dan penyimpangan 
ganda, dua maksim sekaligus. Selama kegiatan observasi pembelajaran berlangsung, banyak siswa yang menyuarakan pendapatnya tanpa memperhatikan prinsip kerja sama. Imbasnya, keadaan kelas menjadi tidak kondusif dan tidak terkendali. Banyak siswa yang menyimpang dari tema pembelajaran dan berbicara sekenanya. Oleh karena itu, siswa dinilai belum dapat menerapkan prinsip kerja sama dalam pembelajaran di kelas. Penyimpangan inilah yang menjadi dasar bagi peneliti untuk dikaji lebih lanjut yaitu, wujud pelanggaran prinsip kerja sama, tujuan, dan fungsi pelanggarannya dalam pembelajaran bahasa Indonesia siswa kelas $X$ dan XI SMK Batik 1 Surakarta.

\section{METODE PENELITIAN}

Penelitian ini merupakan penelitian deskriptif kualitatif. Pendekatan yang digunakan dalam penelitian ini adalah pendekatan kualitatif. Metode yang digunakan adalah metode kualitatif. Metode penelitian kualitatif adalah metode penelitian yang digunakan untuk meneliti pada kondisi obyek penelitian yang alamiah, (sebagai lawannya adalah eksperimen) dimana peneliti adalah sebagai instrumen kunci, teknik pengumpulan data dilakukan secara triangulasi (gabungan) dan hasil penelitian kualitatif menekankan makna daripada generalisasi (Sugiyono, 2016: 1).

Penelitian ini bersifat deskriptif kualitatif. Penelitan yang menggunakan metode deskriptif adalah penelitian yang dimaksudkan untuk melukiskan, menggambarkan, atau memaparkan keadaan objek yang diteliti sebagaimana apa adanya, sesuai dengan situasi dan kondisi ketika penelitian tersebut dilakukan (Ibrahim, 58: 2015).

Data dan sumber data yang digunakan dalam penelitian ini adalah rekaman interaksi dalam pembelajaran bahasa Indonesia di kelas. Informan yang digunakan dalam penelitian ini adalah guru bahasa Indonesia dan siswa. Teknik pengambilan subjek penelitian adalah teknik purposive sampling. Teknik penggumpulan data adalah teknik observasi dan wawancara. Teknik uji validitas data yang digunakan adalah teknik triangulasi teknik dan teori. Penelitian ini menggunakan analisis data milik Miles \& Huberman, yaitu analisis interaktif meliputi pengumpulan data, reduksi data, penyajian data, dan penarikan kesimpulan.

\section{HASIL DAN PEMBAHASAN}

Berdasarkan hasil analisis data, ditemukan tuturan yang melanggar satu maksim dalam prinsip kerja sama dan tuturan yang melanggar dua maksim prinsip kerja sama sekaligus. Pelanggaran prinsip kerja sama tersebut disebut dengan pelanggaran prinsip kerja sama tunggal dan pelanggaran prinsip kerja sama ganda. Pelanggaran terhadap maksim prinsip kerja sama umum terjadi dalam interaksi. Banyaknya tuturan yang melanggar maksim prinsip kerja sama dalam penelitian ini juga terjadi dalam penelitian Tajabadi (2014) yang melakukan penelitian di dalam pengadilan. Pelanggaran maksim kerja sama wajar terjadi dalam persidangan. Partisipan melanggar maksim karena ingin mitra tuturnya lebih memahami maksud dari tuturannya.

\section{Maksim Kuantitas}

Maksim kuantitas mengharuskan penutur memberikan informasi yang cukup, tidak berlebihan, dan seefektif mungkin kepada mitra tutur. Maksim kuantitas menghendaki setiap peserta memberikan kontribusi yang secukupnya atau sebanyak yang dibutuhkan oleh lawan bicaranya (Sulistyo, 2013: 25).

Pelanggaran terhadap maksim kuantitas ditemukan sebesar $17,8 \%$. Tuturan yang menyimpang dari maksim kuantitas ini dilakukan baik oleh guru, maupun oleh siswa. 
Guru:(membaca jawaban kelompok) $\mathrm{Ya}$, sebentar (berjalan menghampiri kelompok lainnya)

Siswa: Pak ngak diccocokkan toh Pak? Guru: Bentar, ada yang tertinggaltinggal gitu kok. Lama banget og. Nanti nek tak kasihke ke kalian jawabannya itu yang belum selesai bisa nyontek.

Tuturan tersebut terjadi di kelas XI Pemasaran antara guru dan siswa. Konteks tuturan tersebut adalah guru sedang meneliti hasil pekerjaan kelompok lain. Kemudian guru menghampiri kelompok lainnya untuk mengambil kertas hasil diskusi. Seorang siswa bertanya apa hasil diskusinya tidak didiskusikan bersama.

Pada tuturan di atas dapat dikatakan guru memberikan informasi yang berlebihan kepada siswa. Setelah melakukan diskusi antar kelompok, guru kemudian mengumpulkan kertas hasil diskusi setiap kelompok. Seorang siswa kemudian bertanya pada guru apakah hasil pekerjaan mereka akan didiskusikan bersama. Jawaban yang diberikan oleh guru ternyata melebihi informasi yang diperlukan oleh siswa. Guru menjawab dengan "Bentar, ada yang tertinggaltinggal gitu kok. Lama banget og. Nanti nek tak kasihke ke kalian jawabannya itu yang belum selesai bisa nyontek.". Dari pertanyaan siswa, seharusnya siswa hanya membutuhkan jawaban "sebentar, ada yang tertinggal-tinggal gitu kok". Akan tetapi guru justru memberikan penjelas lebih dengan mengatakan siswa yang belum akan mencontek jawaban siswa yang sudah. Oleh karena itu, tuturan di atas termasuk kategori tuturan yang menyimpang.

\section{Maksim Kualitas}

Maksim kualitas mewajibkan peserta percakapan untuk menyatakan hal yang sebenarnya (Supriyadi, 2011: 83). Dalam maksim kualitas, penutur dan mitra tutur dituntut untuk selalu menyampaikan suatu informasi yang benar dan didukung bukti yang nyata. Pelanggaran terhadap maksim kualitas ditemukan sebanyak 10.9

$\%$. Jumlah tuturan yang ditemukan adalah 8 tuturan.

Guru: Hayo siapa yang masih ingat?

Siswa: (Tiba-tiba menyahut) Latar belakang..

Guru: (Menjawab pertanyaan siswa) Latar belakang, latar depan, latar samping.

Berdasarkan tuturan di atas, dapat dikatakan bahwa tuturan siswa dan jawaban guru menyimpang dari maksim kualitas. Guru bertanya kepada siswa apa saja unsur intrinsik dalam karya sastra. Latar belakang sudah jelas bukan termasuk dalam unsur intrinsik film. Siswa sengaja menjawab latar belakang meskipun salah. Pelanggaran juga dilakukan oleh guru karena guru bukan membenarkan jawaban siswa, justru sengaja membenarkan jawaban siswa dan memberikan jawaban salah yang mendukung jawaban salah sebalumnya. Pelanggaran terhadap maksim kualitas di atas dilakukan untuk melucu dan mencairkan suasana kelas. Meskipun demikian, pelanggaran maksim tersebut mengganggu komunikasi dan dapat menyebabkan salah persepsi antara siswa. Akibatnya tujuan pembelajaran dapat terganggu dan komunikasi tidak dapat berjalan secara maksimal.

\section{Maksim Relevansi / Hubungan}

Prinsip relevansi atau hubungan ini mengharuskan setiap peserta percakapan memberikan kontribusi yang relevan dengan masalah pembicaraan (Sulistyo, 2013:26). Penutur dan mitra tutur harus selalu memberikan kontribusi yang relevan agar komunikasi dapat terjalin dengan baik dan tujuan komunikasi dapat tersampaikan. Guru : Alur, alur maju, mundur, maju mundur cantik, Syahrini jadine. Trus apa lagi?

Siswa: (menyahut) campuran.

Guru : Lha iyo, campuran, maju mundur cantik Syahrini. Itu adalah unsur intrinsik yang ada di dalam film, drama, 
ataupun karya-karya yang

lainnya. Mungkin itu dulu

dari saya, apabila ada

kesalahan mohon maaf.

Wassalamualaikum.

Bukti tuturan pada data di atas adalah tuturan ketika guru menanyakan dan memberikan penjelasan kepada siswa tentang jenis-jenis alur. Guru sebelumnya bertanya kepada siswa mengenai jenisjenis alur. Siswa di kelas tersebut kemudian menjawab jenis-jenis alur ada alur maju, mundur, dan campuran. Akan tetapi guru justru menjawab "Lha iyo, campuran, maju mundur cantik Syahrini". Jawaban yang diberikan guru tidak relevan dengan pokok pembicaran yang jelas-jelas sedang membicarakan tentang jenis-jenis alur.

\section{Maksim Pelaksanaan / Cara}

Maksim pelaksanaan mengharuskan setiap peserta pertuturan berbicara secara langsung, tidak kabur, tidak taksa, tidak berlebih-lebihan (redundant), dan runtut (Supriyadi, 2011: 90). Penutur ataupun mitra tutur yang berbicara dengan berlebihan, dwimakna, bertele-tele, tidak runtut, dan kabur dikategorikan sebagai pelanggaran maksim pelaksanaan atau cara. Pelanggaran terhadap maksim ini terjadi selama pembelajaran bahasa Indonesia di kelas. Beberapa pelanggaran maksim pelaksanaan/cara yang terjadi adalah sebagai berikut.

Siswa: Pak, itu anaknya Pak?

Siswa: Kui diganti fotoku mesti iso kaet mau (itu diganti dengan fotoku pasti sudah bisa sejak tadi)

Siswa: (Tiba-tiba menyahut) Pak itu putranya Pak Putut?

Tuturan pada data di atas merupakan tuturan ketika seorang siswa berbicara kepada temannya mengenai layar proyektor dari laptop guru yang akhirnya bisa terhubung. Dari tuturan tersebut dapat terlihat siswa 2 berbicara secara ambigu dan tidak runtut. Berbicara tidak runtut karena sebelumnya siswa 1 menanyakan kepada guru apakah foto yang ada di layar anak dari guru. Tiba-tiba siswa 2 bertutur secara lantang kalau fotonya yang digunakan sebagai tampilan laptop dan proyektor sudah tersambung dari tadi. Di sini jelas apa yang siswa 2 lakukan melanggar maksim pelaksanaan/cara karena ia berbicara secara ambigu dan tidak runtut.

\section{Maksim Kuantitas dan Kualitas}

Penyimpangan ganda terhadap maksim kuantitas dan kualitas ini terjadi apabila penutur memberikan informasi yang kurang atau melebihi kebutuhan dari mitra tutur sekaligus memberikan informasi yang tidak didukung oleh bukti yang benar. Penyimpangan ganda terhadap maksim kualitas dan kuantitas hanya ditemukan satu tuturan. Berikut adalah penyimpangan terhadap maksim kuantitas dan kualitas.

Guru : Perhatikan, (tugas halaman

52) itu dipending dulu nanti kita. Sekarang dilihat disaksikan filmnya seperti ketika saya permulaan pembukaan tadi. Silakan film tersebut kalian ulas secara detail mulai dari unsur intrinsik sampai ekstrinsiknya tapi tetap dikertas sobekan sesuai dengan kelompoknya msing-masing, paham? Nanti film saya putar 2 kali. Silakan dicermati jangan ada yang ngomong mergane speakere cilik banget, arek ngowong gede ndadak gowo songkro.

Siswa : Pak, ya bawa yang gede wae

Siswa : Pinjem kelas Ak aja, Pak.

Kutipan tuturan di dalam data tersebut terdapat pelanggaran ganda, yaitu pelanggaran terhaap maksim kualitas dan maksim kuantitas. Penyimpangan terhadap maksim kualitas dan kuantitas secara bersamaan jarang terjadi dalam penelitian ini. Dari total sebanyak 18 tuturan penyimpangan ganda, penyimpangan maksim kuantitas dan kualitas hanya ditemukan 1 tuturan saja. Penyimpangan 
terhadap maksim kuantitas dapat ditemukan di tuturan guru dan jawaban siswa. Guru memberikan informasi yang berlebihan kepada siswa dan siswa memberikan jawaban yang melebihi kebutuhan guru. Tuturan guru pada bagian "Silakan dicermati jangan ada yang ngomong mergane speakere cilik banget, arek ngowong gede ndadak gowo songkro." jelas melanggar aturan maksim kuantitas. Guru memberikan informasi yang tidak dibutuhkan siswa. Begitu juga jawaban siswa "Pinjem kelas Ak aja, Pak." merupakan jawaban yang tidak dibutuhkan oleh guru.

Penyimpangan terhadap maksim kualitas terjadi secara bersamaan dalam tuturan guru. Tuturan guru berikut "Silakan dicermati jangan ada yang ngomong mergane speakere cilik banget, arek ngowong gede ndadak gowo songkro." secara bersamaan melanggar aturan maksim kualitas karena tidak didasarkan bukti. Tuturan guru tersebut hanya untuk mencaikan suasana kelas saja. Guru tidak benar-benar berencana membawa gerobak dari rumah dan tidak berencana membawa pengeras suara yang besar. Karena itu, tuturan tersebut melanggar aturan maksim kualitas.

Berdasarkan hasil penelitian tersebut, terbukti bahwa pelanggar maksim kerja sama masih banyak terjadi. Pelanggaran maksim kerja sama terjadi karena penutur maupun mitra tutur melanggar aturan maksim kerja sama. Menurut Susanti (2016), pelanggaran terjadi karena penutur memberikan informasi yang berlebihan, memberikan informasi yang tidak benar, memberikan informasi yang tidak relevan, dan memberikan informasi yang kurang jelas. Pelanggaran terhadap maksim kerja sama wajar terjadi dalam pembelajaran.

Berdasarkan hasil analisis data pelanggaran maksim ini, ditemukan total sebanyak 73 pelanggaran dari dua pertemuan. Terdapat 55 pelanggaran tunggal terhadap maksim dan 18 pelanggaran ganda. Pelanggaran tunggal yang ditemukan dari tuturan siswa dan guru selama pembelajaran tersebut, sebanyak $10.9 \%$ (8 data) pelanggaran terhadap maksim kualitas. Pelanggaran terhadap maksim kuantitas ditemukan sebanyak 13 tuturan atau $17.8 \%$.

Sebanyak $32.8 \%$ (24 data) merupakan pelanggaran terhadap maksim relevansi. Pelanggaran terhadap maksim relevansi merupakan pelanggaran yang paling banyak terjadi. Sisanya sebanyak 11 tuturan $(15.07 \%)$ merupakan pelanggaran terhadap maksim pelaksanaan atau cara. Pelanggaran terhadap maksim pelaksanaan merupakan pelanggaran yang paling banyak dilakukan setelah maksim relevansi.

Pelanggaran terhadap maksim prinsip kerja sama umum terjadi dalam interaksi. Banyaknya tuturan yang melanggar maksim prinsip kerja sama dalam penelitian ini juga terjadi dalam penelitian Tajabadi (2014) yang melakukan penelitian di dalam pengadilan. Pelanggaran maksim kerja sama wajar terjadi dalam persidangan. Partisipan melanggar maksim karena ingin mitra tuturnya lebih memahami maksud dari tuturannya.

Pelanggaran maksim kerja sama dilakukan oleh guru maupun siswa melalui tuturannya. Pelanggaran dilakukan dengan sengaja maupun tidak sengaja oleh kedua belah pihak. Hal ini sejalan dengan hasil penelitian Fajrin (2016) yang menyatakan bahwa dalam pelanggaran prinsip kerja sama antara penutur dan mitra tutur tidak adanya kerja sama dalam pertuturan yang sifatnya kooperatif.

\section{Tujuan Pelanggaran Maksim Kerja Sama dalam Interaksi Pembelajaran}

Pelanggaran terhadap maksim kerja sama tentunya memiliki tujuan. Menurut Fajar (2009:62) tujuan komunikasi yaitu; (1) memberikan informasi, (2) mendidik, (3) menyenangkan/menghibur, menganjurkan suatu tindakan/persuasi. Kegiatan pembelajaran di kelas tentunya mengharuskan guru dan siswa untuk saling 
berkomunikasi. Komunikasi inilah yang akhirnya dianalisis pelanggaran maksim kerja samanya. Berdasarkan pendapat Fajar (2009:62), tujuan pelanggaran maksim kerja sama diklasifikasikan menjadi 11 tujuan yaitu, menjelaskan, melucu, menyindir, mengganggu, memengaruhi, memarahi/jengkel, memerintah, mengalihkan pembicaraan, mendidik, menggoda, dan menghina. Hasil analisis data tentang tujuan pelanggaran maksim kerja sama tersebut dikuatkan lagi dengan pendapat Jalaluddin Rakhmat dalam Olii (2013: 34) yang merumuskan tujuan berbicara dalam tiga hal; (1) memberitahukan (informatif), (2) memengaruhi (persuasif), menghibur (rekreatif).

Berdasarkan hasil analisis data, ditemukan pelanggaran dengan tujuan untuk menjelaskan terdapat 12 tuturan, pelanggaran dengan tujuan melucu sebanyak 7 tuturan, pelanggaran dengan tujuan menyindir 6 tuturan. Pelanggaran maksim dengan tujuan mengganggu dan menghina masing-masing 2 tuturan. Pelanggaran yang bertujuan untuk menyuruh ditemukan sebanyak 4 tuturan. Lainnya yaitu tujuan untuk memengaruhi, memarahi, mengalihkan pembicaraan, mendidik, dan menggoda ditemukan masing-masing 1 tuturan.

Pelanggaran yang bertujuan untuk memberikan informasi menjadi pelanggaran yang paling sering terjadi. Pelanggaran yang bertujuan untuk memberikan penjelasan biasanya terjadi karena penutur berlebihan, kurang, salah, atau tidak relevan memberikan informasi.

Tujuan berbicara dengan melanggaran maksim kerja sama menurut Tajabadi (2014) adalah menjelaskan maksud tuturan penutur agar tidak ambigu dan jelas. Tujuan lainnya adalah untuk menjelaskan aturan dalam persidangan agar tidak terjadi kesalahan interpretasi dan pemahaman. Penelitian yang dilakukan di SMK Batik I Surakarta ini juga memiliki kesinambungan dengan hasil penelitian milik Tajabadi (2014).
Pelanggaran yang bertujuan untuk memberikan informasi menjadi pelanggaran yang paling sering terjadi. Pelanggaran yang bertujuan untuk memberikan penjelasan biasanya terjadi karena penutur berlebihan, kurang, salah, atau tidak relevan memberikan informasi. Pelanggaran maksim kerja sama dengan fungsi untuk menjelasakan menjadi pelanggaran maksim kerja sama yang wajar terjadi. Pelanggaran yang dilakukan dengan tujuan menjelasakan informasi oleh guru memiliki dampak positif karena siswa menjadi lebih memahami informasi dari guru. Akan tetapi, berdasarkan hasil penelitian pelanggaran maskim kerja sama dengan tujuan menjelaskan informasi juga dilakukan oleh siswa. Pelanggaran yang dilakukan oleh siswa ini beberapa memberi dampak negatif karena mengganggu keefektifan pembelajaran. Beberapa kali guru dan siswa yang lain tergganggu dengan pelanggaran maksim yang dilakukan oleh siswa.

\section{Fungsi Pelanggaran Prinsip Kerja Sama dalam Interaksi Pembelajaran}

Pelanggaran terhadap prinsip kerja sama dapat dilihat dari tuturan seseorang. Pelanggaran terhadap maksim dalam prinsip kerja sama juga memiliki fungsi. Tuturan yang melanggar maksim dalam prisnsip kerja sama dikaji fungsinya berdasarkan teori funggsi bahasa. Untuk menunjukkan hakekat purposif dari komunikasi, Halliday mempergunakan istilah fungsi.

Berdasarkan hasil analisis data diketahui bahwa pelanggaran maksim memiliki 7 fungsi. Fungsi berbahasa yang merupakan teori milik Halliday (1973) menjadi dasar untuk menemukan fungsi pelanggaran maksim. Analisis fungsi pelanggaran maksim dalam prinsip kerja sama belum pernah penulis temukan dalam penelitian sebelumnya. Fungsi bahasa instrumental lebih banyak digunakan oleh guru. Dalam penelitian yang dilakukan oleh Jatmiko (2017) mengenai fungsi bahasa dalam wacana lisan jual beli di 
pasar fungsi instrumental memiliki peran, yakni untuk membuat kesungkanan pembeli. Fungsi instrumental dalam penelitian ini digunakan oleh guru untuk memberikan efek atau membuat siswa melakukan sesuatu sesuai tuturan guru. Hal ini dapat dilihat dalam tuturan guru yang hendak memutarkan film, tuturan untuk memerhatikan guru, tuturan yang menjelaskan tugas yang harus dikerjakan siswa. Tuturan-tuturan tersebut akhirnya membuat siswa melakukan sesuatu dan memiliki tindakan sesuai dengan tuturan guru. Guru meminta siswa untuk memerhatikan dan menganalisis unsur intrinsik film, maka siswa memulai dengan bersiap, tenang, menyiapkan pensil untuk mencatat dan mencatat peristiwa-peristiwa penting.

Pelanggaran dengan fungsi regulasi paling sedikit terjadi dalam penelitian ini. hal tersebut dikarenakan fungsi regulasi bahasa sendiri kebanyakan digunakan dalam peraturan, Undang-undang, perda, perpu dan lain sebagainya. Fungsi regulasi digunakan oleh guru untuk menerapkan aturan yang harus dipatuhi oleh siswa selama kegiatan pembelajaran berlangsung. Fungsi regulasi bahasa selama di kelas tidak dilakukan oleh siswa, tetapi diterapkan oleh guru. Guru memiliki kewenangan untuk mengatur pembelajaran, pemilihan materi, dan metode pembelajaran. Oleh karena itu, siswa harus menaati fungsi regulasi bahasa yang digunakan oleh guru dalam tuturannya.

\section{Fungsi Instrumental}

Fungsi instrumental ini menyebabkan peristiwa-peristiwa tertentu terjadi. Fungsi instrumental memiliki kekuatan untuk membuat mitra tutur melakukan sesuatu atau bergerak sesuai dengan tuturan penutur. In the instrumental component there are just five of these: the response element, the object of desire, the service desaired, the amemity and the quantifier. The selection which the child makes of particular configuration of option within his meaning potential is organized as a structure; but t is a structure in which the language is being made to serve for him (Halliday, 1973: 29).

Tuturan di atas menggunakan bahasa sebagai fungsi instrumental. Penggunaan tersebut dapat dilihat dari tuturan "Silakan film tersebut kalian ulas secara detail mulai dari unsur intrinsik sampai ekstrinsiknya tapi tetap dikertas sobekan sesuai dengan kelompoknya msing-masing, paham? Nanti film saya putar 2 kali.". Tuturan guru tersebut membuat siswa dikenai pekerjaan untuk menganalisis unsur intrinsik film. Tuturan tersebut membuat siswa melakukan kegiatan persiapan, konsentrasi, dan tenang. Tuturan "Silakan dicermati jangan ada yang ngomong mergane speakere cilik banget, arek ngowong gede ndadak gowo songkro." juga menyebabkan mitra tutur melakukan sesuatu sesuai dengan instruksi guru. Tuturan tersebut berfungsi menjadikan siswa tenang dan konsentrasi memperhatikan.

\section{SIMPULAN}

Berdasarkan hasil penelitian kualitatif dengan pendekatan pragmatik untuk menemukan wujud pelanggaran, tujuan pelanggaran, dan fungsi pelanggaran maksim dalam prinsip kerja sama yang terjadi selama pembelajaran bahasa Indonesia kelas X Desain Komunikasi Visual serta XI Pemasaran SMK Batik 1 Surakarta, dapat ditarik kesimpulan sebagai berikut. Pelanggaran terhadap prinsip kerja sama terbukti terjadi selama pembelajaran bahasa Indonesia di kelas X Desain Komunikasi Visual dan XI Pemasaran. Berdasarkan hasil analisis data, ditemukan tuturan yang melanggar satu maksim dalam prinsip kerja sama dan tuturan yang melanggar dua maksim kerja sama sekaligus. Keduanya disebut dengan pelanggaran tunggal dan pelanggaran ganda.

Tujuan pelanggaran maksimada 11 yaitu, (1) menjelaskan, (2) melucu, (3) menyindir, (4) mengganggu, 
memengaruhi, (6) memerintah, (7) memarahi/jengkel, (8) mengalihkan pembicaraan, (9) mendidik, (10) menggoda, dan (11) menghina. Fungsi pelanggaran maksim dalam prinsip kerja sama berdasarkan teori fungsi bahasa Halliday (1973: 27) adalah sebagai berikut; (1) fungsi instrumental sebanyak 11

\section{REFERENSI}

Cummings, Louise. 2007. Pragmatik Sebuah Perspektif Multidisipliner. Yogyakarta: Pustaka Belajar.

Effendy, Onong Uchjana. 2006. Ilmu Komunikasi Teori dan Praktek. Bandung: PT Remaja Rosdakarya.

Fajar, Marheni. 2009. Ilmu Komunikasi: Teori dan Praktik. Jakarta: Graha Ilmu.

Halliday, M. A. K. (1973). Exploration of Language Study. London: Edward Arnold.

Moedjiono dan Dimyati, Moh. 1992. Strategi Belajar Mengajar. Departemen Pendidikan dan Kebudayaan.

Rahardi, Kunjana. 2005. Pragmatik: Kesantunan Imperatif Bahasa Indonesia. Yogyakarta: PT Gelora Aksara Pratama. tuturan, (2) fungsi regulasi sebanyak 2 tuturan, (3) fungsi representatif sebanyak 4 tuturan, (4) fungsi interaksional sebanyak 3 tuturan, (5) fungsi personal sebanyak 6 tuturan, (6) fungsi heuristik sebanyak 5 tuturan, dan (7) fungsi imajinatif sebanyak 3 tuturan.
Sulistyo, Edy Tri. 2013. Pragmatik Suatu Kajian Awal. Surakarta: UNS Press

Tajabadi, Dowlatabadi, \& Mehrin. (2014). Grice Cooperative Maxims in Oral Arguments: The Case of Dispute Settlement Counsils in Iran. Precedia Social and Behavioral Sciences Volume 98, 2014: 1859 1865. Diperoleh pada 01 Juli 2018, dari https://www.sciencedirect.com/scien ce/article/pii/S1877042814027074/p dfft?md5=8b658a8e37082dd802537 1262851ae5c\&pid=1-s2.0S1877042814027074-main.pdf

Tarigan, Henry Guntur. 2008. Berbicara Sebagai Suatu Keterampilan Berbahasa. Bandung: Penerbitan Angkasa Banung.

Olii, Helena. 2013. Pubic Speaking. Jakarta: PT Indek. 